Archived version from NCDOCKS Institutional Repository http://libres.uncg.edu/ir/asu/

\title{
Appalachl̈ăn
}

B O O N E, N O R T H C A R O L I N A

\section{Political Opposition And Reform Coalitions In Jordan}

\author{
By: Curtis R. Ryan
}

\begin{abstract}
Jordanian politics has seen decades of pro-reform and pro-democracy political activism, but with little effective change on the Jordanian political system itself. This analysis explains how and why the regime has resisted more than cosmetic reform and democratic change. It also examines in detail old and new avenues of opposition reformist activism in the kingdom, from leftist political parties and the Islamist movement to new forms of prodemocracy activism in the form of grassroots coalitions, youth movements and social media activism. As both government and opposition in Jordan are affected by the 2011 Arab uprisings, this analysis examines the past and present possibilities for democratic political opposition and for an effective and unified coalition for reform in Jordan.
\end{abstract}

RYAN, C. (2011). Political Opposition and Reform Coalitions in Jordan. British Journal of Middle Eastern Studies, 38(3), 367-390. Publisher version of record available at: http://www.jstor.org/stable/23264245 


\title{
Political Opposition and Reform Coalitions in Jordan
}

\author{
CURTIS R. RYAN*
}

\begin{abstract}
Jordanian politics has seen decades of pro-reform and prodemocracy political activism, but with little effective change on the Jordanian political system itself. This analysis explains how and why the regime has resisted more than cosmetic reform and democratic change. It also examines in detail old and new avenues of opposition reformist activism in the kingdom, from leftist political parties and the Islamist movement to new forms of pro-democracy activism in the form of grassroots coalitions, youth movements and social media activism. As both government and opposition in Jordan are affected by the 2011 Arab uprisings, this analysis examines the past and present possibilities for democratic political opposition and for an effective and unified coalition for reform in Jordan.
\end{abstract}

\section{Introduction}

The year 2011 began with street demonstrations in Amman and other cities across Jordan, inspired by the Tunisian and Egyptian revolutions, and calling for reform-but not yet revolution or regime change-in the Hashemite Kingdom. The anger and resentment that led to these demonstrations were palpable and had been growing for a very long time. It reminded many in Jordan and elsewhere of similar unrest and social protest in April 1989. Those earlier demonstrations had turned quickly into riots, triggered in large part by austerity measures implemented as part of an International Monetary Fund (IMF) stabilisation programme. But the demonstrations of 1989, like those of 2011, expanded quickly to include protest not only against difficult economic circumstances, but also against government corruption, while calling for greater and more genuine democratisation.

What alarmed the Hashemite regime in both cases was the large presence and even predominance of ethnic East Jordanian or Transjordanian citizens in the demonstrations. ${ }^{1}$ In short, the demonstrators themselves could not be dismissed as

\footnotetext{
*Department of Government and Justice Studies, Appalachian State University, Boone, North Carolina 28608, USA. E-mail: ryanc@ appstate.edu

${ }^{1}$ The largest ethnic division within Jordanian politics is that between Palestinian Jordanians (those whose roots are west of the Jordan river, many of whom came to Jordan as refugees of the Arab-Israeli wars of 1948 and 1967) and East Jordanians, also known as Transjordanians or East Bankers, since they trace their roots east of the Jordan river. In general, the Hashemite state, army, security services and public sector have been dominated by East Jordanians, while Palestinian Jordanians have come to dominate the private sector. As the regime's own neoliberal economic reforms shift Jordan's economy from the public to the private sector, ethnic tensions have increased within the kingdom.
} 
the 'usual suspects' of opposition in Jordan-leftist parties, Islamists, and/or Palestinian activists. Rather, the demonstrations ranged across the ideological spectrum within Jordan, and even spanned the ethnic divide between Palestinian and East Bank Jordanians. Put another way, both traditional opposition forces and bedrock constituencies of the regime itself seemed to be out on the streets facing that very regime. And in both cases, the latter group seemed to outnumber the former. In 1989, then-King Hussein (1952-1999) responded by dismissing the extremely unpopular government of Prime Minister Zaid al-Rifa'i (1985-1989) and by initiating a broad-ranging programme of political and economic liberalisation. Similarly, in 2011, King Abdullah II dismissed the equally unpopular government of Prime Minister Samir al-Rifa'i (Zaid al-Rifa'i's son, 2009-2011), and pledged to restore the kingdom to the path of more genuine political and economic reform.

With dramatic regime change occurring in other Arab states, Jordan's opposition has grown larger and more coordinated in its attempts to push the regime back towards the reform process, calling for greater democracy and the curbing of monarchical powers, in order to make Jordan more of a constitutional monarchy. Jordan's 1952 constitution, still in place, provides for a strong executive authority vested in the king, a bicameral legislature and an independent judiciary. Reformers of almost all stripes tend to argue, however, that since the 1950s the balance of power has shifted almost entirely towards the monarchy. So, Jordan remains a monarchy with a parliament and a constitution, but I would argue that it is not yet a constitutional monarchy; that is, one where the powers of the monarchy are more limited, where the elected parliament is stronger, where the judiciary is truly independent, where the government is democratically elected and where the three branches of government check and balance one another.

The Hashemite regime thus appeared to be stuck-seemingly for years-at a crossroads between more liberalisation and democratisation, or a more authoritarian path. While Jordan has oscillated between these two extremes, it has never become a full blown police state, unlike so many other states in the region. But neither has it allowed full liberalisation and democratisation, despite a very promising start in 1989. Instead, the Jordanian state has alternated between periods of openness and repression over the years. As a kind of middle case that is neither fully authoritarian nor fully democratic (although it leans towards the former), Jordan can therefore be best described as a 'hybrid regime' or 'liberalising autocracy', in which the regime has allowed moderate levels of political reform, not to transform the system but to preserve it. $^{2}$ Correspondingly, the opposition has for decades called on the regime to choose the path of greater democratisation, and to move beyond mere cosmetic reforms, often by forging broad-based, yet often fluid 'reform coalitions'. ${ }^{3}$ The present study explores

\footnotetext{
${ }^{2}$ See, for example, D. Brumberg, 'The Trap of Liberalized Autocracy', Journal of Democracy, 13(4) (2002), pp. 56-68; T. Carothers, 'The End of the Transition Paradigm', Journal of Democracy, 13(2) (2002), pp. 5-21; and C. Ryan and J. Schwedler, 'Return to Democratization or New Hybrid Regime? The 2003 Elections in Jordan', Middle East Policy, 11(2) (2004), pp. 138-151.

${ }^{3}$ Throughout this analysis, the phrase 'reform coalition' refers to organised alliances between political parties, professional associations, trade unions, civil society organisations and other political movements to collectively seek specific political and economic reform and change. For a further discussion of the 'reform coalition', see also the introductory contribution by $\mathrm{H}$. Kraetzschmar, 'Mapping Opposition Cooperation in the Arab World: From Single-Issue Coalitions to Transnational Networks'. The analysis draws on extensive field research and interviews with individuals in all the above types of groups, reform activists and government officials (including those for and against democratic change) conducted on frequent visits to Jordan between 1989 and 2011.
} 
regime-opposition dynamics in Jordan since the early 1990s, focusing on past and present attempts at opposition cooperation and their success in challenging the Hashemite regime to initiate genuine liberalising reform.

In the analysis that follows, I posit that the ingredients for a broad-ranging and even unified reform coalition exist in Jordanian politics and that since 1989 we have seen numerous attempts at creating such coalitions against authoritarian policies; yet that despite their efforts at unity and activism, opposition reformers have had very little success in achieving meaningful political change. Why? I argue that the regime has long used structural and institutional means (especially through ever-changing laws regarding elections, parties and parliamentary participation) to check and contain the power of opposition forces. It has also tended to use a divide and rule strategy, splitting opposition forces along the lines of the many fissures in Jordanian society-between Palestinians and Jordanians, leftists and Islamists, and even within the Islamist movement itself-and thus rendering difficult, if not impossible, any effective opposition coordination. This analysis will explore each of these issues, and why reform coalitions, both past and present, have thus far been frustrated in their efforts at pressuring the incumbent regime into liberalising reforms, but it will also examine how the dynamics of opposition have changed in the context of the Arab uprisings-including both traditional and new reform coalitions-and what this in turn may mean for the prospects of reform and democratisation in the kingdom.

In the sections below, I will first explain the state of reform efforts in the kingdom, and hence the extent of opposition frustrations. The analysis then turns to the 'traditional' opposition in the form of opposition political parties and examines the successes and failures of these forces in gaining political power and influence over the decision-making process through the ballot box. ${ }^{4}$ It is in this context also that efforts by the country's traditional opposition at forging crossideological/cross-party cooperation will be explored. Lastly, this contribution examines the current state of unrest and opposition in Jordan in the context of the 2011 Arab uprisings, and what this may suggest for the emergence of new forms of democratic opposition and potentially a new reform coalition in Jordanian politics.

\section{The reform question in Jordan}

Jordan began its liberalisation process in response not to the Arab uprisings of 2011, but to widespread popular unrest in April 1989. Even though the motivations were defensive on the part of the regime, it initiated a political and liberalisation process that included the revival of elections and parliamentary life. ${ }^{5}$ At the time, Jordan's liberalisation looked to be the most promising and the most extensive in the entire Arab world. Over time, the process expanded to include the lifting of martial law, the legalisation of political parties, loosening of restrictions on the media, and six rounds of national parliamentary elections

\footnotetext{
${ }^{4}$ See also E. Lust, 'Elections under Authoritarianism: Preliminary Lessons from Jordan', Democratization, 13(3) (2006), pp. 456-471; and J. Gandhi and E. Lust, 'Elections under Authoritarianism', Annual Review of Political Science, 12(1) (2009), pp. 403-422.

${ }^{5}$ R. Brynen, 'Economic Crisis and Post-Rentier Democratization in the Arab World: The Case of Jordan', Canadian Journal of Political Science, 25(1) (1992), pp. 69-97; M. Mufti, 'Elite Bargains and the Onset of Political Liberalization in Jordan', Comparative Political Studies, 32(1) (1999), pp. 100-129; and G.E. Robinson, 'Defensive Democratization in Jordan', International Journal of Middle East Studies, 30(3) (1998), pp. 387-410.
} 
(in 1989, 1993, 1997, 2003, 2007 and 2010). ${ }^{6}$ Economically, Jordan moved steadily towards a neoliberal model of development, with emphasis on privatising state-owned industries, lowering barriers to trade and encouraging extensive foreign investment.

Yet while economic liberalisation has proceeded apace since 1989, political reform has since faltered, stalled and at times regressed. Over the past two decades Jordan has, in short, experienced both liberalisation and de-liberalisation in its political life, as the state has at times retreated from earlier reforms. This was especially clear in the aftermath of Jordan's peace treaty with Israel in 1994. ${ }^{7}$ Erstwhile King Hussein's regime showed little patience for opposition to the Jordanian-Israeli peace treaty, and thus Jordan's 'political opening' began to close. In 1999, however, following the succession to the throne from King Hussein to King Abdullah II, it appeared that the door of reform was opening once again. ${ }^{8}$

When King Abdullah first ascended the throne, Jordan's domestic and regional climate was initially remarkably stable, and the new king allowed municipal elections to take place as scheduled in July 1999. It seemed that for the first time in years the kingdom might finally be able to move beyond its difficult geography and its various security concerns, to renew and consolidate the reform process at home. But since that time, regional and domestic security concerns have continually trumped attempts at domestic political reform. The brief period of regional stability turned out to be little more than a mirage. When the second Palestinian uprising or intifada erupted in September 2000 (in the West Bank and Gaza), the Jordanian government worried about its impact on domestic stability, including fears that Israel would expel thousands and perhaps even millions of Palestinians to Jordan. With the intifada still raging, the US war in Afghanistan (and the Jordanian regime's support for it) beginning in 2001 only widened the gap between the government and its opposition. By 2003, US forces had invaded Jordan's eastern neighbour, Iraq, undermining Jordan's regional security still further. Not only was the kingdom wedged between escalating conflicts, but it also had to absorb waves of Iraqi refugees fleeing the US invasion and the widespread unrest, insurgency and terrorism that followed.

The security concerns have consistently served to derail the opposition goal of greater democratisation, while economic liberalisation has moved steadily forward-especially in the form of privatisation-and has had a profound social impact. As the state sector declines in size, so does the social welfare component of previously reliable state employment. Jordanians complain consistently about rising unemployment, underemployment, poverty and corruption among business and government elites. These economic frustrations have fuelled social unrest and motivated many Jordanians to mobilise politically and press the state to return to

\footnotetext{
${ }^{6}$ C.R. Ryan, 'Elections and Parliamentary Democratization in Jordan', Democratization, 5(4) (1998), pp. 194-214; Ryan and Schwedler, 'Return to Democratization or New Hybrid Regime?', pp. 138-151; H. Hourani et al., Dirasat fi al-Intakhabat al-Niyabiyya al-Urduniyya [Studies in the 1997 Representative [Parliamentary] Elections] (Amman: Al-Urdun al-Jadid Research Center, 2002).

${ }^{7}$ L.A. Brand, 'The Effects of the Peace Process on Political Liberalization in Jordan', Journal of Palestine Studies, 28(2) (1999), pp. 52-67; J. Schwedler, 'Don't Blink: Jordan's Democratic Opening and Closing', MERIP Press Information Note, 3 July 2002, http://www.merip.org/mero/mero070302.

${ }^{8}$ For a broader analysis of the four major transitions in Jordanian politics since 1989 (political liberalisation, economic liberalisation, peace with Israel, and the royal succession), see C.R. Ryan, Jordan in Transition: From Hussein to Abdullah (Boulder, CO: Lynne Rienner, 2002).
} 
its long-promised political liberalisation and reform programme. ${ }^{9}$ Yet anti-reform hardliners in the regime (and especially in the intelligence services or mukhabarat) have for decades used security concerns as their main argument against opening the political system to greater public participation. As long-time democracy activist Mustafa Hamarneh has noted, however, this regime argument relies on a kind of reverse logic. 'To say if we open up, we sow instability is a statement I flatly reject,' he argues. 'I believe it's the other way around; the lack of opening up sows the seeds of instability. ${ }^{10}$ Regime obsessions with security concerns, in short, actually undermine security. Within the field of comparative politics, then, this mirrors the international relations theory concept of the 'security dilemma', in which states in the international arena unwittingly undermine their own security, even as they try to enhance it. In domestic politics, authoritarian and semiauthoritarian regimes often do much the same thing in state-society relations, building their security apparatus, but also simultaneously undermining their legitimacy and security vis-à-vis their own societies. ${ }^{11}$

In an analysis of stalled reform in Jordan, the International Crisis Group (ICJ) in 2003 suggested that the 'deficit of democratic representation' might provide the spark for real conflict in the kingdom, even going so far as to compare Jordan to Algeria. But the same report also remarked upon the weakness of Jordan's political opposition, arguing that 'too often, opposition parties and civil society have contented themselves with vacuous slogans and unrealistic proposals that do not resonate with the people and further undermine the credibility of political action'. ${ }^{12}$ Analysing rising tensions and unrest in the kingdom, the ICG noted that governmental reform efforts seemed to focus mainly on procedural democracythat is, the act of elections-without providing meaningful channels for genuine participation, transparency and accountability. ${ }^{13}$ While the lack of these factors does not lead automatically to corruption, they nonetheless make it more likely, especially in the context of extensive economic liberalisation, as the state shifts from a public to a private sector-dominated economy. Furthermore, it is quite telling that the single greatest point of unity across the Jordanian political spectrum is the belief that corruption is a major problem in politics, society and the economy.

Investigating the unrest that led to six deaths in recurrent violence in the southern town of Ma'an in November 2002, the ICG argued that:

Nevertheless, the regime's Achilles heel is the feeble bond of trust between most citizens and the state. Meaningful relationships are based primarily on family or tribal loyalties, with religion also an important social glue. The state, however, is largely absent from

\footnotetext{
${ }^{9}$ K. Abdul-Wahab, 'Reaping What We've Sown: The Economic Protests', JO Magazine, 28 April 2011. On the economic reform process, see A.M. Peters and P.W. Moore, 'Beyond Boom and Bust: External Rents, Durable Authoritarianism, and Institutional Adaptation in the Hashemite Kingdom of Jordan', Studies in Comparative International Development, 44(3) (2009), pp. 256-285; and S. Alissa, Rethinking Economic Reform in Jordan: Confronting Socioeconomic Realities (Washington, DC: Carnegie Endowment for International Peace, Carnegie Papers Number 4, July 2007).

${ }^{10}$ M. Hamarneh, 'Political Truths: Interview', Jordan Business, March 2009, p. 58.

${ }^{11}$ For a detailed discussion of this phenomenon in the context of the Arab world, see C. Ryan, 'Security Dilemmas in Arab Politics', in C. Ryan, Inter-Arab Alliances: Regime Security and Jordanian Foreign Policy (Gainesville: University Press of Florida, 2009), pp. 23-42.

12 International Crisis Group, 'The Challenge of Political Reform: Jordanian Democratisation and Regional Instability', Middle East Briefing, Amman/Brussels, 8 October 2003, p. 1. ${ }^{13}$ Ibid.
} 
these relations, being broadly perceived as non-transparent, unresponsive and unaccountable. $^{14}$

The report also cited King Abdullah himself, who was quoted the same year in an American newspaper stating that:

The leadership of the Middle East don't understand that 50 percent of the population is under eighteen, and if they don't get going to create some means for real participation for these young people, they are going to have serious problems. ${ }^{15}$

That was, then and now, good advice for Jordan and all other Arab regimes. Yet the Jordanian monarchy does not seem to have been following its own advice. Indeed, the struggle over increased participation and reform has dominated Jordanian politics for decades, even under the reign of King Abdullah from 1999 onwards.

In an attempt to achieve political reform, King Abdullah in 2004 appointed the kingdom's former foreign minister and prominent reformer Marwan Muasher to the post of Deputy Prime Minister for Reform. ${ }^{16}$ In that capacity, Muasher was tasked to lead a broad-based committee of Jordanians (drawn from government and across society) in creating what was called the 'National Agenda' for reform. That effort resulted in calls for broader political reform within the kingdom, including the rights of women, and a deepening of Jordan's nascent civil society specifically. As Muasher noted at the time, even the concept of civil society has sometimes been reduced to include only charitable NGOs, and not political parties, professional associations or trade unions, effectively de-politicising the concept. Consequentially he called for a broader conceptualisation of civil society, to include all of these types of organisations, independent of the state itself, with goals ranging from social to economic to political. In this way, he surmised, political liberalisation (in Jordan and elsewhere) can finally move forward, but only with a strengthened civil society as its base. ${ }^{17}$

Unveiled in 2005, the National Agenda, however, was met with overt hostility by many anti-reform hardliners within the regime, and with considerable indifference on the part of a Jordanian public that seemed to have grown tired of new top-down initiatives and slogans emanating from the regime itself. In the words of one NGO activist, 'We have many regime slogans: think big, act big; Jordan First; political development; the National Agenda-these are Western style marketing slogans. They work more for marketing outside the country, but not inside the country'. ${ }^{18}$ Similarly, another NGO director argued that:

This is the problem, the contradiction between speeches and implementation. We have now had Jordan First, political development and the new ministry for it, and now the National Agenda. Continually new programmes are launched, but still with little effect. Little actual involvement. The quota for women, for example, or the National Center for Human Rights, these are both ok but very small steps. The National Center for Human Rights, for instance, is not actually fully independent of the government. These are advances in relatively small details ... We don't suffer like the people of Syria or Saudi Arabia, but we don't need to compare ourselves to them. We are stable and have a better

\footnotetext{
${ }^{14}$ Ibid., p 2.

15 J. Diehl, 'Jordan's Democracy Option', The Washington Post, 21 September 2003.

${ }^{16}$ See Muasher's own discussion of the struggle for the National Agenda for reform. M. Muasher, The Arab Center: The Promise of Moderation (New Haven: Yale University Press, 2008), pp. 246-253.

${ }^{17}$ Ibid.

${ }^{18}$ Interview with the author, Amman, Jordan, May 2005.
} 
economic situation. But why do we have to pay a political price for this? This should simply be the norm. We have a mature and educated population. Few listen to the real extremists here. Palestinians for example may have real grievances but we don't see mobs in the street. We all try to solve things with soft pressure. ${ }^{19}$

It may be, however, that faith in 'soft pressure' has begun to fade, as people in 2010 and 2011 were indeed in the streets demanding real reform, and most were East Jordanians. Muasher himself points not to problems at the grassroots but in the ruling elite. In his words:

The problem is that the political system doesn't want (reform) - the political elite, the intelligence services, and the status quo in Jordan and the Arab world in general. Opening the system to them boils down to reducing their privileges. The excuses are endless. But the bottom line is that they don't want their privileges to go. ${ }^{20}$

In the years following the 1999 accession of King Abdullah, both conservative and reform constituencies seemed to think that a young and active king was on their side. Yet in more recent years what is striking is that both sides seem to believe that they have been abandoned-and that the king is on the other side. Reform activists from civil society organisations and political parties argue that the monarchy has retrenched and is more authoritarian now than it was in 1999. Right-wing 'old guard' elites, in contrast, seem to feel that the regime has gone too far, selling the country out in its quest for neoliberal economic development. This debate has also taken on a steadily more nationalist tone, as ethnic identity politics has risen sharply in response to domestic and regional crises. Conservative East Jordanian nationalists, for example, increasingly question 'reform' at all; and often argue that it is not about liberalisation or democratisation, but is too often mistaken for being synonymous with Palestinian empowerment. ${ }^{21}$ In any case, what is more broadly clear is that after years of political stagnation, social and political dissatisfaction with the status quo is the prevalent mood in the kingdom, cutting across ethnic, religious, gender and ideological lines. If Jordanians are so united in their desire for change, then, can they also be united in political activism to achieve the much desired democratic reforms?

\section{Opposition Political Parties and Elections}

Much of the traditional locus of opposition in Jordan has been the country's legal political parties. Yet Jordan's party system, aside from the Islamist movement, is notoriously weak. Political parties were illegal in the kingdom for more than 30 years, until the Jordanian regime re-established elections for parliament in 1989 after a long hiatus, and legalised political parties in $1991 .^{22}$ Many in the opposition

\footnotetext{
${ }^{19}$ Interview with the author, Amman, Jordan, May 2005.

${ }^{20}$ Author interview with Dr. Marwan Muasher, Washington, DC, 1 May 2010.

${ }^{21}$ For a discussion of resurgent ethnic identity politics in Jordan, see C.R. Ryan, "We Are All Jordan" ... But Who is We?', Middle East Report Online, 13 July 2010, http://www.merip.org/mero/mero071310 (accessed 13 July 2010).

${ }_{22}$ The Hashemite monarchy banned political parties in 1957, following a failed military coup attempt against the regime by Nasserist and leftist officers. The overthrow of the neighbouring Hashemite monarchy in Iraq in 1958, and the killing of the entire Hashemite royal family there, served to underscore the regime's conviction that the greatest threat to its survival - in the 1950s-came from Nasserist, leftist, and Pan-Arab parties and movements. On this period, see U. Dann, King Hussein and the Challenge of Arab Radicalism, 1955-1967 (New York: Oxford University Press, 1989); and K. Salibi, The Modern History of Jordan (London: I.B. Tauris, 1998), pp. 197-221.
} 
welcomed the return of parties, elections and more active parliamentary life as a return to the more vibrant politics of the $1950 \mathrm{~s}^{23}$ Many have also complained, however, of the chronic weakness of Jordan's political parties and party system, which they see as being in marked contrast to the more vibrant party political era of the 1950s. Yet as Ellen Lust has demonstrated, that is not actually true. ${ }^{24}$ Parties and party systems are indeed weak in Jordan, but that was also the case in the 1950 s. In short, parties and the party system were weak then, and they are weak now.

What has changed, however, is the reversal in fortunes across the ideological spectrum. Even if the parties themselves did not command large segments of voters, the earlier liberalisation period saw weak Islamist parties competing with then-ascendant leftist parties in the heyday of Pan-Arabism, with Pan-Arab nationalist, Ba'thist, socialist and communist parties all competing for votes. In the 1950s, the secular left and Pan-Arabist parties competed not only with the then-small Islamist movement, but more so with each other. In short, crossideological alliances between parties were rare. In the post-1989 period, the reverse is true. The Islamist movement-in the form of the Jordanian Muslim Brotherhood (MB) and its legal party the Islamic Action Front (IAF)-has been the most popular and best organised of the opposition forces, while the parties of the left remain to some extent in the shadow of the Islamists, competing for far smaller segments of the electorate. This shift in hegemony within the Jordanian party system, from the secular left to religious right, reflects broader trends across the entire region from the 1950s to the present. As Michaelle Browers has demonstrated, the entire region has seen an ideological transformation featuring not only the rise of Islamist movements, but also the rise of moderation and accommodation between the secular left and religious right, in which parties and movements that once seemed diametrically opposed have found some elements of common ground, leading to previously unthinkable alliances and coalitions in Arab politics. In her words, 'the relationship among competing ideologies of opposition in the contemporary Arab region is best characterized as accommodationist, with strategic alliances forming among more pragmatic and moderate wings of otherwise opposed ideological factions of marginalized groups'. ${ }^{25}$

In the Jordanian case, this transformation has led leftist parties to work more often with, rather than against, the Islamist movement, and just as importantly, it has led them to abandon many intra-left rivalries to work with each other. At present, the most consistently active leftist parties in Jordanian politics include the Jordanian Communist Party (JCP), the People's Democratic Party (PDP, better

\footnotetext{
${ }^{23}$ Jordanians were so ready for the resumption of multi-party elections, in fact, that a series of studies had already been published on Jordanian political parties in anticipation of the return of party life. See, for example, A. Abu Khusa, Al-Dimuqratiyya wa al-Ahzab al-Siyasiyya al-Urduniyya [Democracy and Jordanian Political Parties] (Amman: Middle East Publishing Company, 1991); M.A.S. al-Abdalat, Kharita al-Ahzab al-Siyasiyya al-Urduniyya [Map of Jordanian Political Parties] (Amman: Dar al-Ubra, 1992); S. Sways, 'Kharita al-Ahzab al-Siyasiyya fi al-Urdun' [A Map of Political Parties in Jordan] (Amman: Al-Urdun al-Jadid, 1990), pp. 122-141; R. al-Khatib Iyad, Al-Tayarat al-Siyasiyya $f i$ al-Urdun wa Nas al-Mithaq al-Watani al-Urduni [Political Tendencies in Jordan and Text of the Jordanian National Charter] (Amman: al-Matba'a al-Wataniyya (National Printing House), 1991).

${ }^{24}$ E.M. Lust-Okar, 'The Decline of Jordanian Political Parties: Myth or Reality?', International Journal of Middle East Studies, 33(4) (2001), pp. 545-569.

${ }^{25}$ M. Browers, Political Ideology in the Arab World: Accommodation and Transformation (Cambridge: Cambridge University Press, 2009), p. 176.
} 
known as Hashd and linked to the Democratic Front for the Liberation of Palestine), the Popular Unity Party (PUP, linked to the Popular Front for the Liberation of Palestine), and two Jordanian Arab Socialist Ba'ath parties (one historically with links to Syria and one to Iraq). Yet in the post-1989 era, perhaps because of their small size, these parties are far more likely to try to cooperate and ally with one another than was the case in the 1950s and 1960s, when political parties often rivalled one another, in effect reproducing domestically the external ideological conflicts of inter-Arab regional politics and the 'Arab Cold War' ${ }^{26}$ Even combined, however, these leftist and Pan-Arab nationalist parties tend to garner far less popular support (either in terms of membership or voters) than the political wing of the Jordanian Islamist movement, the IAF. ${ }^{27}$

Jordan's Muslim Brotherhood is actually as old as the Hashemite monarchy itself. Unlike its counterparts in Syria or Egypt (before 2011), the Jordanian Muslim Brotherhood has enjoyed a more cooperative relationship with the state as a loyal opposition organisation that accepted the legitimacy of its Hashemite rulers. And unlike Hamas, the Jordanian Muslim Brotherhood has no militant wing, and instead focuses on democratic activism, and on organising through a civilian party (the IAF), membership in professional associations and through extensive charity work. ${ }^{28}$ The Jordanian Muslim Brotherhood is a fairly broad movement that includes different wings, usually seen as 'hawkish' or 'dovish' in their approaches to elections, participation and cooperation with the regime itself. More militant Qutbist Islamists or ultra-conservative (but historically avoiding participation entirely) Salafi strains of Islamism have, however, generally appeared outside the framework of the Jordanian Muslim Brotherhood. ${ }^{29}$

Given their long history of organisation and activism, Jordan's Islamists were well placed for electoral success once the liberalisation process began in 1989 . Since then, Jordan has held six rounds of national parliamentary elections, with multiple changes to the electoral law, and hence to the rules of the game. In the first of these elections, in 1989, an assortment of leftist party candidates secured together a mere 13 of the 80 seats in parliament, while the Muslim Brotherhood and independent Islamists garnered 34 seats. $^{30}$ Together, however, these opposition parliamentarians constituted a majority and used their numbers to elect an Islamist leader, Dr. 'Abd al-Latif al-'Arabiyyat (1989-1993), as speaker of parliament. Surprised and dismayed at the success of the Islamists in particular, the regime quickly moved to change the parliamentary electoral rules from the 'block vote' system, whereby voters have as many votes as there are seats in a

${ }^{26}$ M. Kerr, The Arab Cold War: Gamal 'Abd al-Nasir and His Rivals, 1958-1970 (London: Oxford University Press, 1970).

${ }^{27}$ On Jordanian parties and the party system, see Al-Dimuqratiyya fi al-Hayat al-Dakhiliyya li al-Ahzab al-Siyasiyya al-'Arabiyya [Democracy in the Practice of Arab Political Parties] (Amman: Al-Quds Center for Political Studies, 2010); and Al-Qu'anin al-Nazimat li al- 'Amal al-Hizbi fi al-Urdun [Revisiting Political Party Legislation in Jordan] (Amman: Al-Quds Center for Political Studies, 2010).

${ }^{28} \mathrm{~J}$. Schwedler, Faith in Moderation: Islamist Parties in Jordan and Yemen (Cambridge: Cambridge University Press, 2006); Q. Wiktorowicz, The Management of Islamic Activism: Salafis, the Muslim Brotherhood, and State Power in Jordan (Albany: State University of New York Press, 2000).

${ }^{29}$ C.R. Ryan, 'Islamist Political Activism in Jordan: Moderation, Militancy, and Democracy', Middle East Review of International Affairs, 12(2) (2008), pp. 1-13.

${ }^{30}$ In the 1989 elections, all candidates technically ran as independents since parties remained illegal. From the 1993 elections onwards, however, candidates have been able to run with legal party affiliations. Underscoring the weakness of the Jordanian party system, however, most candidates in any election have been non-partisan or independent, rather than from Islamist, leftist, or nationalist parties. On the 1989 elections, see K.S. Abu Jaber and S.H. Fathi, 'The 1989 Jordanian Parliamentary Elections', Orient, 31 (1990), pp. 67-86. 
given district, to a 'one-person one-vote' system, hoping this would forestall similar opposition inroads in future elections. Indeed, it was assumed that left with only one vote to cast, voters would place family and kinship ties above ideological considerations in their choice of candidates, thus diminishing the electoral prospects of Islamist contestants. ${ }^{31}$ As intended by the regime, the revised electoral system produced a marked reversal of fortunes for Islamist and leftist parties in the 1993 election, reducing their representation to 22 and 7 out of 80 parliamentary seats, respectively. ${ }^{32}$ Following the 1993 debacle, and in what would become a recurring theme, opposition parties decided to boycott the 1997 elections entirely, demanding a change in the electoral law. ${ }^{33}$ The resultant 1997-2001 legislature was thus made up almost entirely of loyalist and conservative tribal elites, while opposition forces remained effectively unrepresented in parliament until the next elections in 2003.

Following the royal succession from King Hussein to King Abdullah II in 1999, parliament was dissolved, but new elections-expected in 2001-were delayed for two full years to 2003, due mainly to the regime's security concerns amid regional turmoil. As mentioned earlier, these regional conflicts included the 2000 Palestinian uprising against Israeli rule in the West Bank and Gaza, and the US invasions of Afghanistan in 2001 and Iraq in 2003. But in 2003, the elections were finally held under yet another electoral law. The new law increased the number of parliamentary seats from 80 to 104, with the introduction of new (but still uneven) electoral districts, and added six more parliamentary seats in a specific quota for women's representation. Held in June that year, the elections themselves returned some opposition representation to the Jordanian legislature, with 17 seats going to the IAF, including one to Hayat al-Musayni, its first female candidate. Five independent Islamists were also elected. ${ }^{34}$

Despite the return of the opposition to parliament in 2003, struggles between the regime and opposition parties continued to centre around electoral reform, with the latter demanding the abolition of the 'one-person one-vote' system and the redrawing of electoral districts, all of which had been designed to curb the potential power of opposition parties. By 2007, however, the regime was even less inclined to respond to opposition demands, and seemed in fact to be highly concerned with electoral successes of Islamist movements elsewhere in the region, from Hamas in Palestine to Hizbullah in Lebanon. With these security concerns in mind, the 2007 elections, presided over by then-Prime Minister Marouf Bakhit (2005-2007), were perhaps the most egregiously rigged contests of the post-1989 period. The regime had been alarmed by the 2005 al-Qa'ida terrorist attacks in Amman and by the 2006 electoral success of Hamas in the Palestinian territories, and seemed determined to prevent Islamist inroads at all costs. ${ }^{35}$ That strategy may have worked, with Islamist candidates winning a mere six out of 110 parliamentary seats, but it also undermined the legitimacy of the electoral process

\footnotetext{
${ }^{31}$ Author interviews with opposition activists, journalists and government officials, Amman, Jordan, June 2010, December 2010 and June 2011.

${ }^{32}$ M.C. Wilson, 'Jordan: Bread, Freedom, or Both?', Current History (February 1994), pp. 87-90. For details on the 1993 elections, see also Robinson, 'Defensive Democratization in Jordan'; and Ryan, 'Elections and Parliamentary Democratization in Jordan'.

${ }^{33}$ For further details on the 1989, 1993 and 1997 elections, see Ryan, Jordan in Transition, pp. 15-45.

${ }^{34}$ On the 2003 elections, see Ryan and Schwedler, 'Return to Democratization or New Hybrid Regime?'

${ }^{35}$ A. Susser, 'Jordan: Preserving Domestic Order in a Setting of Regional Turmoil', Middle East Brief No. 27, Crown Center for Middle East Studies, Brandeis University, March 2008, pp. 4-5.
} 
and of the resultant parliament itself. Even the monarchy seemed to eventually acknowledge this legitimacy deficit, as it later dismissed the entire parliament two years before the completion of its term.

With new elections scheduled for 2010, the regime yet again introduced minor amendments to the parliamentary electoral law, though without changing the actual voting system as demanded by the opposition. ${ }^{36}$ As in the past, the elections were conducted on a 'one-person one-vote' basis, prompting the IAF to boycott the poll. Most leftist parties, meanwhile, chose to participate in the elections, but with almost no success. In fact, not a single opposition party candidate won a seat outright in the new parliament. The only exceptions were Abla Abu Elbeh, the secretary general of the leftist Hashed Party, who secured a seat as one of the 12 MPs elected on the women's quota. Similarly, Wafa Bani Mustafa, an Islamist candidate, was elected after she defied the IAF boycott and won a women's quota seat. $^{37}$

As this discussion has illustrated, opposition parties have since 1989 had limited success in securing representation in the Jordanian parliament. Leftist parties have been particularly ineffective, leading one democracy activist to dismiss them as 'somehow Left without being progressive. They are old Left. Just oppositionist as a career. They still act like they are an opposition in exile. They don't know how to work inside the system, even when they are in it' ${ }^{38}$ The Islamist movement, on the other hand, has a larger popular following, is better organised and has had greater success in past elections, but regards the various electoral laws as specifically aimed at minimising its representation, power and influence in the Jordanian legislature. In fact, over the past two decades, regime and opposition parties have been at loggerheads over the rules of the electoral game, with the latter pressing for a return to a block voting system or (even better) a shift to a proportional representation (PR) system based on party lists. Opposition parties on the political left and right insist that they remain weak precisely because of Jordan's 'oneperson one-vote' electoral laws that encourage citizens to vote along family, clan or tribal lines. In a PR system, they argue, parties would be strengthened through the voting process and citizens would cast votes based on policies and party platforms rather than family ties and/or personalities. ${ }^{39}$

\section{Opposition Parties and Cross-ideological Cooperation}

The literature on cross-ideological cooperation in the Middle East suggests that leftist-Islamist cooperation and alliances are indeed more likely in the contemporary period than at any time in the past; yet scholars differ on how viable, effective or durable such alliances and coalitions can be in Arab politics.

\footnotetext{
36 The 2010 electoral law kept the uneven districts, but added four new seats for Amman, Irbid and Zarqa (cities with large Palestinian populations), and doubled the women's quota from six to 12 seats in parliament. For an analysis of the details and reactions, see C.R. Ryan, 'Jordan's New Electoral Law: Reform, Reaction, or Status Quo?', Foreign Policy, Middle East Channel, 24 May 2010, http://mideast.foreignpolicy.com/posts/2010/05/24/ jordan_s_new_electoral_law_reform_reaction_or_status_quo (accessed 24 May 2010).

37 On the 2010 elections and their aftermath, see C.R. Ryan, 'Déjà Vu All Over Again? Jordan's 2010 Elections', Foreign Policy, Middle East Channel, 15 November 2010, http://mideast.foreignpolicy.com/posts/2010/11/15/ jordanians_go_to_the_polls (accessed 15 November 2010).

${ }_{38}$ Author interview with democracy activist, Amman, Jordan, June 2001.

${ }^{39}$ On the state and the Islamist movement, see Al-Dawla wa al-Ikhwan 1999-2008 [The State and the Brotherhood 1999-2008] (Amman: Al-Quds Center for Political Studies, 2008); and Al-Din wa al-Dawla: al-Urdun [Religion and the State: Jordan] (Amman: Al-Quds Center for Political Studies, 2010).
} 
While Browers has argued for the importance of cross-ideological cooperation trends in the region, Cavatorta has challenged this, noting the difficulties in practice of actually achieving cooperation, especially in the cases of Morocco and Tunisia. ${ }^{40}$ The Jordanian case actually illustrates both trends; attempts at greater leftist-Islamist cooperation, for example, but also limitations to effective opposition coordination or unity.

Within Jordan, despite differences in ideological and even religious orientation, opposition parties of all shades actually agree on several key political issues, thereby providing a plausible basis for unified action and the formation of broadbased reform coalitions. Most have been sharply critical of the peace treaty with the state of Israel, for example. They have demanded that the regime cease normalising relations with Israel, and some even demand the abolition of the treaty itself. ${ }^{41}$ Within domestic politics and policy, the country's opposition parties also insist that future prime ministers and cabinets should be drawn from parliament in a truer model of a parliamentary system, rather than royally appointed, pending only the formality of parliamentary approval, and, most crucially, that the extant electoral law be fundamentally changed.

However, despite this unified set of opposition demands towards the Hashemite rulers, and in contrast to regime-opposition dynamics elsewhere in the region, the struggle for reform has remained confined to public policy and the direction of the state (including demands for democratic reform) and never challenged the state itself as a Hashemite monarchy. What is more, it appears that the diverse set of opposition parties and actors find it easier to agree on foreign policy issues, rather than on domestic ones, especially regarding the situation in the Palestinian territories and Iraq. ${ }^{42}$ Indeed, regional political issues have on many occasions united not only the opposition, but also many current or past regime elites themselves. The 2003 US invasion of Iraq, for example, was opposed by state and society in Jordan, regime and opposition alike, albeit to varying degrees. Ninety well-known Jordanian political figures even signed a public petition, presented to the king, condemning the US war as aggression, and in effect putting the monarchy itself on notice not to soften its opposition to US policy, regardless of the depth of the US-Jordanian alliance. ${ }^{43}$

But besides general agreement on foreign policy issues, that they have almost no hope of affecting, and some convergence on domestic reform demands, can opposition parties agree on key issues and perhaps work together as a broader reform coalition in pressuring the regime into liberalising reforms? The record for

\footnotetext{
${ }^{40}$ Browers, Political Ideology in the Arab World; F. Cavatorta, 'Divided They Stand, Divided They Fail: Opposition Politics in Morocco', Democratization, 16(2) (2009), pp. 137-156; and F. Cavatorta, 'More Than Repression: Strategies of Regime Survival: The Significance of Divide et Impera in Morocco', Journal of Contemporary African Studies, 25(2) (2007), pp. 187-203. See also Haugbolle/Cavatorta and Wegner/Pellicer in this issue for theoretical and empirical discussions demonstrating the limits of ideological cooperation.

${ }^{41}$ Opposition to the 1994 Jordanian-Israeli peace treaty led leftist and Islamist activists to organise, through the political parties and the professional associations, an 'anti-normalisation' campaign from 1994 onwards, so that the peace remains a cold one between the two governments, but with limited links between the two societies. See P.L. Scham and R.E. Lucas, "Normalization" and "Anti-Normalization" in Jordan: The Public Debate', Israel Affairs, 9(3) (2003), pp. 141-164.

${ }^{42}$ For extensive analysis of cross-ideological cooperation and its limits in Jordan, see J. Clark, 'Threats, Structures and Resources: Cross-ideological Coalition Building in Jordan', Comparative Politics, 43(3) (2010), pp. 101-120; J.A. Clark, 'The Conditions of Islamist Moderation: Unpacking Cross-ideological Cooperation in Jordan', International Journal of Middle East Studies, 38(4) (2006), pp. 539-560; and J. Schwedler and J.A. Clark, 'Islamist-Leftist Cooperation in the Arab World', ISIM Review, 18 (2006), pp. 10-11.

${ }^{43}$ F. Sawalha, 'Opposites Attract on Petition to Declare War on Iraq "Illegal"', Jordan Times, 1 April 2003.
} 
political opposition in Jordan shows that opposition parties and independent activists have at times splintered, and at times worked together. In her analyses of political activism in Jordan and elsewhere in the Arab world, Ellen Lust has emphasised the importance of context and structures between government and opposition. We can expect opposition to increase during economic crises, for example, but will this opposition work together, or in competition? Lust argues that the answer depends on whether the regime itself has excluded all opposition, or divided its opponents between loyalist and radical camps. In the former case, opposition parties should be expected to coalesce against the state, whereas in the latter, the divide and rule regime stratagem should be expected to work. Prior to the 1989 liberalisation process in Jordan, all political parties were illegal, and hence all were excluded from the system, even though the regime had a decadeslong understanding with the Muslim Brotherhood so that the latter operated as essentially a loyal opposition. But as the 1989 economic crisis hit, opposition forces from the secular left and the religious right were able to mobilise together to push the regime towards greater reform. ${ }^{44}$

Elites from these and other opposition elements, along with conservative royalist forces, participated in the 1989 elections that followed and later in the 1991 crafting of the National Charter (al-Mithaq al-Watani). The Charter formalised the relationship between regime and opposition, allowing for legal opposition activism and greater pluralism in public life, in return for loyalty to the Hashemite monarchy. But the shift in electoral rules prior to the 1993 election undercut opposition strength in parliament, paving the way for the regime to make peace with Israel, without an opposition majority in parliament blocking ratification of the accords. The regime's move to curb parliamentary opposition, however, only led to greater opposition coordination both inside and outside parliament itself.

A first step towards cooperation in the new multi-party era was taken in 1995, when the IAF and seven leftist parties formed the so-called 'Anti-Normalization Committee'. While the opposition had failed to block the signing of a peace treaty with Israel, this committee was determined to prevent any normalisation of relations between various sectors of the two societies. ${ }^{45}$ In addition, the committee called for greater political liberalisation and domestic reform. The regime's response, however, was quite the opposite, as it moved to repress dissent and counter the opposition bloc. Regime hostility seemed to help further unite the opposition coalition, which expanded later in 1995 to include 13 opposition parties through the Higher Committee for the Coordination of National Opposition Parties (HCCNOP). The HCCNOP was intended, then and now, to be a forum bringing together all opposition parties in an effort to coordinate and pool their efforts for reform and democratisation. As will become apparent below, while the HCCNOP remains the most prominent party-driven reform coalition in the country, numerous additional groups, organisations and coalitions-often with overlapping membership-have emerged on the Jordanian political scene since the 1990s. Although varying in number and composition, these additional forces should not necessarily be seen as rival or replacement organisations to the HCCNOP, but

${ }^{44}$ E. Lust-Okar, 'Divided They Rule: The Management and Manipulation of Political Opposition', Comparative Politics, 36(2) (2004), p. 169; E. Lust-Okar, Structuring Conflict in the Arab World: Incumbents, Opponents, and Institutions (New York: Cambridge University Press, 2005).

${ }^{45}$ See Scham and Lucas, "Normalization" and "Anti-Normalization" in Jordan'. 
rather as multiple and mutually reinforcing efforts at opposition coordination in the kingdom.

In 1996 yet another economic crisis-and another IMF austerity programmeled the HCCNOP to call for a rejection of the IMF measures, especially the lifting of subsidies on bread and other staple foods. In the bread riots that followed, the opposition coalition maintained its pressure on the regime to shift away from its faith in neoliberal market reforms, arguing that privatisation and austerity measures were helping some in the wealthy elite, while harming average Jordanians. ${ }^{46}$ In 1997, the HCCNOP called for major changes in the electoral law, including equal population districts and the abrogation of the 'one-person onevote' system in favour of the previous block vote system. When these demands remained unmet, the opposition called for a national boycott of the 1997 elections, yielding, as mentioned above, a new parliament with few opposition voices (including only a handful of independent Islamist activists and leftist figures that had broken ranks with the boycott coalition).

In 1998, opposition parties sought to further institutionalise and broaden their coalition by forming the Conference on National Reform (CNF), drawing together leftist parties, the Islamist movement, and independent opposition figures. In short, the newly formed Conference was intended to broaden opposition coordination beyond the forces hitherto represented within the HCCNOP, to include non-party opposition activists as well as the traditional parties. ${ }^{47}$ Since then, opposition parties and activists have met continually to discuss their interests, goals, strategies and tactics, sometimes within the framework of the HCCNOP and sometimes through the broader CNF.

Yet despite these organised efforts to unite the country's political opposition, and even institutionalise it in a reform coalition, there are still significant areas of difference between and within opposition forces that render such cooperation difficult to sustain. The Islamist movement plays an important leadership role within the HCCNOP, for example, but is more than willing to break ranks from the opposition coalition, depending on the issue. As Janine Clark has shown, this often turns on gender issues and questions about reforming laws that especially affect women, such as personal status laws, divorce laws and laws regarding violence against women in the name of 'honour crimes'. ${ }^{48}$ In general, the Islamists have proven to be both moderate and reactionary. The Muslim Brotherhood and IAF remain moderate in the sense of believing in reform and greater democracy, but they are by no means moderate in terms of policy and legislation. ${ }^{49}$ For instance, the movement opposed progressive attempts to change all the above laws, finding itself therefore in opposition to the monarchy, but allied with royalist conservative political parties. The leftist parties were themselves divided on these issues, but in general a broader pattern emerges. On democracy and liberalisation, it is the opposition reform coalition that is more progressive than the monarchy, but on social legislation, often the monarchy is far more progressive than the opposition parties. Similarly, most opposition parties opposed the Hashemite regime's introduction of a quota in 2003 to guarantee women's representation in parliament;

\footnotetext{
${ }^{46}$ C.R. Ryan, 'Peace, Bread, and Riots: Jordan and the International Monetary Fund', Middle East Policy, 6(2) (1998), pp. 54-66.

${ }^{47}$ Lust-Okar, 'Divided They Rule', p. 172.

${ }^{48}$ Clark, 'The Conditions of Islamist Moderation', p. 555.

${ }^{49}$ Ibid., pp. 555-556.
} 
but the Islamists soon had to reverse field, when the first woman elected under the quota was herself an Islamist.

More recently, in 2010, a broad range of opposition parties and NGOs together called yet again for major changes in the electoral law, preceding the 2010 elections. Facilitated in part by the National Center for Human Rights, which was led by former prime minister Ahmad 'Ubaydat (1984-1985), the reform-oriented parties and NGOs called for a one-person two-vote, or mixed electoral system, in which citizens could vote for an individual district representative, and also for a party list at the national level. Together these groups formed an ad hoc umbrella coalition, the National Coalition for Reform (NCR). ${ }^{50}$ Informal and little institutionalised, the newly formed NCR included the previous groups and coalitions noted above (including most members of the HCCNOP), while expanding to also include independent activists and representatives of prodemocracy NGOs. Although Ahmad 'Ubaydat formally 'led' this particular coalition, he was viewed by its members as effectively the main coordinator of the movement, but not as in any way in charge of any of the elements within the coalition itself. ${ }^{51}$

Bringing together a broad range of opposition groups and activists, the ingredients seemed to have come together once again for a fairly unified and comprehensive reform coalition, with clear policy proposals for electoral change and the potential to pressure the regime toward meaningful change. Yet the regime, to quote one opposition activist, 'is really skilled at killing momentum' ${ }^{52}$ Despite months of opposition activism, reform proposals and extensive discussions across the Jordanian public sphere, the state issued the new electoral law, with the same gerrymandered districts, and no party lists or proportional representation. ${ }^{53}$ Thus, although the opposition was unified, well organised and presented viable policy alternatives, it remained yet again largely ineffective in actually achieving its desired reform objectives.

One of the reasons why Jordan's opposition has been so ineffective in pressuring the regime for democratic change may lie in the fact that aside from the Islamists, most political parties carry little support in society. Indeed, while many democracy activists are active party members, most are not, and some seem to see the country's parties as weak and perhaps even as an obsolete form of opposition. ${ }^{54}$ They are generally viewed as ineffective, and it is that very weakness of the parties and the party system that has led many non-party reform activists to be openly scornful of the parties. As one such activist writer suggested, 'The Islamists and leftists, they are covered in dust' ${ }^{55}$ Others, such as Hisham Bustani, have argued that the problem with the opposition is even more endemic. According to Bustani, the traditional opposition parties amount to an 'official' opposition that has far too many links to the regime itself. The time is therefore

${ }^{50}$ O. al-Rantawi, 'Coalition Presses for Electoral Reform in Jordan', Arab Reform Bulletin, 14 April 2010.

${ }^{51}$ Similarly, even when groups do overlap considerably, most activists do not seem to view one group as subsuming another, or one as being above another. They simply overlap, and individuals therefore are often participants in multiple organisations, groups or coalitions. Author's interviews with democracy activists, Amman, Jordan, June 2010, December 2010 and June 2011.

${ }_{52}$ Author interview with a youth and social media activist, Amman, Jordan, June 2011.

53 Ryan, 'Jordan's New Electoral Law'.

${ }^{54}$ This point was made to me consistently in interviews with democracy activists, journalists and government officials, especially in June 2010, December 2010 and June 2011.

${ }^{55}$ Author interview, Amman, Jordan, June 2011. 
more than ripe for an alternative opposition, beyond that of the traditional parties, which - again aside from the Islamists-is able to mobilise widespread popular support and thus more effectively challenge the regime's authoritarian policies. According to Bustani, this alternative opposition has recently emerged in the form of groups such as the Jordanian Campaign for Change, better known as 'Jayeen'a mainly non-party-based reform coalition-although he argues that even this group might be problematic due to regime connections for at least some 'opposition' elites, and limited in its mass appeal, due to its emphasis on a unitary (and seemingly East Jordanian) national identity. For Bustani this emphasis is inherently limiting; he refers to it as an 'isolationist vision'. He explains the alternative opposition as follows:

What are the constituents of this 'alternative opposition'? Its main elements include the Jordanian Social Left Movement, the Jordanian National Initiative, the National Progressive Current, the National Committee of Military Veterans, the Jordanian Writers Association, the Nationalist Progressive Current, in addition to very small groups such as the Democratic Youth Union, the Philosophy Society, the Socialist Thought Forum, the Assembly of Circassean Youth, and the Association Against Zionism and Racism. All the above-mentioned groups (with the exception of the National Progressive Current, the National Committee of Military Veterans, and the Nationalist Progressive Current) form the so-called 'Movement of the Jordanian People.' And all those groups (without exception) form 'The Jordanian Campaign for Change - Jayeen,' and are closely allied at both the politics and logistical levels. ${ }^{56}$

While many activists in both the 'official' and 'alternative' opposition are dedicated to genuine democratic reform, others seem to be using the movements as ways to counter other elites, and to get themselves back in office. Worse, Bustani argues, is the tendency for opposition coalitions like the Jordan Campaign for Change (Jayeen), to adopt the regime's own Jordanian nationalist rhetoric, and to emphasise a Jordanian national movement that is distinct from a Palestinian movement, thereby alienating much of the Jordanian population. ${ }^{57}$

Jordan at present, therefore, now has not one but several reform coalitions with overlapping memberships and objectives, including party-led movements (such as the HCCNOP), non-party-led reform movements (such as Jayeen) and combinations of both (such as 'Ubaydat's National Coalition for Reform) ${ }^{58}$ While they all agree that democratic change is essential, the question remains whether they are talking about the same reforms. I turn to this question below. For as the Arab uprisings shook the Middle East to its foundations, all the above parties, organisations and coalitions took to the streets, as Jordanians too demanded reform in a kind of de facto national 'street coalition' for change.

\section{The 2011 Arab Uprisings and Reformist Opposition in Jordan}

As noted above, the 2010 electoral law and parliamentary elections were disappointing for those concerned with real reform and political liberalisation, but

\footnotetext{
${ }^{56} \mathrm{H}$. Bustani, 'The Alternative Opposition in Jordan and the Failure to Understand the Lessons of the Tunisian and Egyptian Revolutions', Jadaliyya, 20 March 2011, http://www.jadaliyya.com/pages/index/959 (accessed 20 March 2011).

${ }_{57}^{57}$ Ibid., and author interview with Hisham Bustani, Amman, Jordan, 12 June 2001.

${ }^{58}$ Oraib Rantawi, director of the pro-democracy Al-Quds Center for Political Studies, estimated that the number of coalitions and youth movements had already reached more than 30 , and was continuing to grow. Author interview with Oraib Rantawi, Amman, Jordan, 12 June 2011.
} 
they did yield for the Hashemite regime the type of parliament it seemed to prefer, with a clear majority of MPs not from opposition parties but rather 'independents', whose backgrounds were loyalist, royalist, tribal and mostly Transjordanian. Yet the new government of Prime Minister Samir al-Rifa'i, appointed for a second time by the king in December 2010, barely had time to exhale before the Tunisian and Egyptian revolutions toppled longstanding dictators. In Jordan, the ripple effects and demonstrated efficacy of people in street activism in Tunis and Cairo led to marches and demonstrations that brought thousands into the streets in Amman and other Jordanian cities and towns. Like the demonstrations across the Arab world, Jordanians too marked theirs with heavy loads of patriotic symbolism, while demanding democratic change. But unlike their Tunisian and Egyptian counterparts, the Jordanian demonstrators demanded the dismissal of the Rifa' $i$ government, but not regime change itself.

The demonstrations themselves sometimes varied in terms of participants and some demands. There have been, for example, protests for greater media and press freedom, and protests against state repression in other Arab countries (such as Libya, Syria and Yemen), while other much smaller demonstrations demanded the release of numerous Salafi Jihadists in Jordanian prisons. Clearly, these demonstrations had nothing whatsoever in common and included few overlaps in terms of participants and objectives. But the larger demonstrations-those that numbered in the thousands-were demonstrations for democratic reform and echoed calls that opposition parties and civil society groups had been making for years. A Jordanian journalist covering the protests, and supportive of democratic reform efforts, summarised the emerging opposition consensus:

What needs to change? We need to bring back checks and balances, and to respect the original constitution. It envisioned that the parliament would do two main things, legislate and hold government accountable. But over time, it really does neither, and power shifted almost entirely to the monarchy. ${ }^{59}$

After years of struggles over the nature of elections and election laws, opposition demands have thus shifted to the nature of parliament itself. Many Jordanians today view parliament as merely a pro-Hashemite tribal assembly. All democracy activists, regardless of ideological, ethnic, or religious background, seem to agree that in addition to electoral reform (still a major demand), parliament too must change and become a more genuine legislative body, which, in turn, implies changes regarding the nature of government and of the constitution itself.

This suggests, in other words, that in addition to diverse grievances, there is also a coherent and consistent set of demands that most opposition forces (and many regime reformers themselves) agree on. For all the diversity of the coalitions, parties and groups noted above, both old and new coalitions and activists agree on at least the following set of reform demands: (1) they want parliament to be a body that actually legislates, rather than simply implementing cabinet initiatives or royal decrees; (2) they all want government to be drawn from the elected representatives of the people-that is, they want a more truly parliamentary system, rather than a royally appointed government separate from parliament; (3) they all demand an end of the 'one person one vote' electoral system, potentially replaced with a mixed electoral system, coupled with the ability for voters to cast

${ }^{59}$ Author interview, Amman, Jordan, June 2011. 
multiple votes (up to the number of representatives for a given district); (4) they all call for fewer restrictions on media, press and publications, including a shift away from timid and often self-censored reporting, and an end to mukhabarat interference in the media and in public life in general; (5) they all demand an end to corruption and the establishment of a more independent judiciary to hold the corrupt accountable for their actions; and (6) many want districts that are equal in size rather than gerrymandered, although this point remains controversial among democracy activists.

At present, electoral districts are unevenly representative, designed to increase rural representation (and hence usually conservative, pro-regime, East Jordanian communities), while limiting urban representation (since the largest cities such as Amman, Irbid and Zarqa have large Palestinian populations). The ethnic implications of redistricting (implying a major shift from East Jordanian to Palestinian empowerment) therefore suggest that this particular reform question remains the single most divisive one among the various opposition parties and coalitions. We can assume, therefore, that elites that feel threatened within the regime, particularly those in the mukhabarat, will exploit these differences by stoking these fears, in an effort to prevent the emergence of a single, unified and truly national coalition for change in Jordan. ${ }^{60}$

While the above reform demands all suggest political changes, it is worth underscoring that in Jordan and across the Arab world, part of the revolt against the status quo seems to be not just a revolt against particular governing systems, but also a rejection of neoliberal economic policies. These are associated in the minds of many across society with enriching the already wealthy, while removing the previous social safety nets of large public sectors with greater guarantees of employment and social welfare. In the Jordanian context, these economic policies have also had profound ethnic implications, given the traditional predominance of Palestinians in the private sector and East Jordanians in the public sector. While leftist and Islamist parties have for years regarded neoliberal reform with suspicion and even overt hostility, in more recent years even traditionally proregime conservatives have joined the chorus against this particular type of economic reform. Conservative East Jordanian nationalists have increasingly charged their own regime with corruption and selling off Jordan's national assets in the name of short-term profits. They have even been so bold as to link these policies with the queen herself, comparing Queen Rania to the deposed first ladies of Tunisia and Egypt. ${ }^{61}$

Indeed, economic grievances have been a large part of the motivation for the 'southern movement' in particular; that is, largely non-party-based activism outside of the capital, Amman, and based rather in towns such as Karak, Ma'an, Tafila and Theiban. The activities of the 'southern movement' overlap with the 'alternative opposition', alluded to by Bustani (above), but include largely independent youth organisations such as the Karak Popular Youth Movement, the Free Tafileh Movement, and the Ma'an Popular Movement for Change and

\footnotetext{
${ }^{60}$ In my own personal observations of Jordanian politics over more than 20 years, I would argue that the pattern is for anti-reform journalists, activists or officials to insist that pro-democracy opponents are an ethnic or religious threat to the identity of Jordan. In short, anti-reformers try to create disunity by exploiting social divisions and fears, and then (ironically) accuse their opponents of threatening 'national unity'. Indeed, there is no more pervasive phrase in the anti-reform lexicon than invoking national unity against opponents, putting them instantly on the defensive, and effectively challenging their loyalty and patriotism.

${ }^{61}$ BBC News, 'Jordan Tribes Criticize Queen Rania's “Political Role”', 8 February 2011.
} 
Reform. ${ }^{62}$ Each of these groups expresses particular pride in the role of the (largely East Bank Jordanian) south in creating the political reform revivals of both 1989 and 2011, and each focuses in particular on the problems of privatisation, Amman-centric investment and development, and especially government corruption related to all of the above. ${ }^{63}$ Opposition to economic liberalisation thus certainly carries the potential to unite otherwise disparate ideological forces, such as leftists, Islamists and secular nationalists. But paradoxically, it is also just as likely to create deeper fissures in Jordan's already established political fault lines, such as Palestinian and East Jordanian identity politics. As Nicolas Pelham has noted, this has led to a kind of reversal, in which some conservative East Jordanian nationalists have become harshly critical of the regime, while Palestinians in Jordan's business community find themselves in the role of defenders of the monarchy. ${ }^{64}$ In short, anti-neoliberalism has at times brought together a very broad group of activists, for reform away from privatisation and towards a revitalisation of the social welfare role of the state. Yet the ethnic tensions inherent in the same controversial issue carry the potential to tear that very coalition apart.

Ultimately, whether reformers and democracy activists can unite effectively or not, the widespread discontent across almost all sectors of Jordanian society suggests that clearly much needs to change in terms of both political and economic reform in the kingdom for the security and well-being of both state and society. In that context, Jordan's wide-ranging political opposition, spanning opposition parties and numerous civil society organisations, has had a long history of organisation and activism, but with little effect on government policy. The state, in turn, has long practised a politics of inclusion and co-optation of some opposition, while allowing others to vent some level of frustration, and actively attempting to divide still others. ${ }^{65}$ But many of these mechanisms-from co-optation to coercion-are now all too familiar to opposition forces. And given the large presence of increasingly politicised and active youth in public demonstrations in Jordan-youth who very often identify with neither the state nor its traditional opposition forces-it is also clear that older methods are no longer enough to contain opposition. 'The palace also seems to always see challenges even when they are actually opportunities,' noted one Jordanian journalist. 'They could embrace and even lead reform efforts. But they do not. The times have changed, and the tools of rule need to change with them. ${ }^{66}$ Also emphasising change, a veteran reform and democracy activist noted the importance of generational change in the expanding Jordanian reform movement, and the extensive use of

${ }^{62}$ T. Luck, 'Southern Protests Continue', Jordan Times, 8 July 2011.

${ }^{63}$ While many Jordanian youth movements were inspired to reform activism by the Tunisian and Egyptian revolutions, the first of these movements actually emerged on 7 January 2011 (before the 25 January 2011 Egyptian revolution) in the form of the Theiban Popular Movement for Change in Theiban, Jordan, calling for an end to corruption and the ouster of the government of then-Prime Minister Samir al-Rifa'i. For a discussion of the dynamics of organisation of many of the movements, see T. Luck, 'Despite Differences, Youth Movements Still Depend on Traditional Parties to Materialise', Jordan Times, 29 July 2011.

${ }^{64}$ N. Pelham, 'Jordan's Balancing Act', Middle East Report Online, 22 February 2011, http://www.merip.org/ mero/mero022211 (accessed 22 February 2011).

${ }^{65}$ See, for example, Muhammad Abu Rumman's analysis of state-opposition relations and divisions within the Islamist movement in 'Jordan's Parliamentary Elections and Islamist Boycott', Arab Reform Bulletin, 20 October 2010.

66 Author interview in Amman, Jordan, June 2011. 
social media, especially Facebook, Twitter and blogging, to organise demonstrations and activism:

The parties are not near people's hearts and minds. That's why they have these Facebook groups. That's their political parties. It is like an election, people signing up and 'liking' and agreeing to support a figure or group or demonstration. Social media is their device to convert and share their aspirations. But the mukhabarat are also now trying to infiltrate social media groups. But people just aren't afraid anymore. Measures that used to scare people just don't now. They are sure that they are smarter than the regime. They are just not afraid. ${ }^{67}$

Youth activists have emerged to re-invigorate the longstanding efforts of reform and democracy activists. Often organised as youth or 'Shabab' groups via Facebook, the groups and individuals stay connected through multiple social media platforms, not just through Facebook, Twitter and blogging but also simply through cell phone calls, texting and direct personal contact. The Shabab movements in 2011 played a large role in the demonstrations that ousted the Rifa' $i$ government, and pulled together to form the March 24 Shabab Movement, staging an all day and night demonstration for democracy and reform in the Ministry of Interior Circle in Amman. While youth groups may have led the organisation, like all demonstrations it quickly fanned out from there as groups and individuals contacted each other. The result was an exercise in genuine grassroots democracy. The demonstration may have been organised by the newer opposition coalition or 'alternative opposition', but it came to include participants from the more traditional opposition as well. ${ }^{68}$ The peaceful demonstrators represented the diversity of Jordan itself: men and women, young and old, rich and poor, Muslim and Christian, secular and Islamist, and included East Jordanians, Palestinians and Circassians. As was true of most 2011 demonstrations, however, the majority were East Bankers or Transjordanians, and they marked their democratic protests with extensive nationalist symbols-red check keffiyas (rather than black and white checkered Palestinian keffiyas), Jordanian flags, flag face paint, blaring nationalist songs, and so on. Yet despite all this effort, the demonstrations were broken up the next morning by armed and angry nationalist youths, known as bultajiyya or 'thugs', who scattered the protesters. Hundreds were injured and one died, apparently of a heart attack. ${ }^{69}$

What was intended as a pinnacle type of moment turned quickly from democracy to bedlam, but has since served as a rallying cry for reform. Still more groups and events have emerged, with the 24-25 March 2011 dates remembered and commemorated as perhaps high and low points in Jordanian reform and activism. Since then, in addition to frequent Friday demonstrations throughout the kingdom in 2011, youth activists have continued to organise and also to broaden their networks to engage as diverse a cross-section of Jordanian society as possible. They organised, for example, public discussions on reform, social media, the constitution and even the role of the mukhabarat, in what are known as the

\footnotetext{
${ }^{67}$ Author interview in Amman, Jordan, June 2011.

${ }^{68}$ Since demonstrations took place across Jordan from the beginning of January onwards throughout 2011, they have varied in composition. Those in the hundreds tended to include either party activists (usually leftists and Islamists together) or youth movements, but those that grew to include thousands of demonstrators seemed to span the spectrum of traditional and newer forms of opposition.

${ }^{69}$ See the account by democracy activist and blogger Naseem Tarawneh, 'The Quick Death of Shabab 24 and What it Means for Jordan', Black Iris of Jordan [blog], 26 March 2011, http://www.black-iris.com/2011/03/26/ the-quick-death-of-shabab-march-24-and-what-it-means-for-jordan/ (accessed 30 July 2011).
} 
Hashtag debates. And true to form regarding their savvy use of technology, the youth activists made sure to live stream the debates online. ${ }^{70}$

Meanwhile the number of youth movements continues to expand to include virtually every town and city in the country. In addition to the southern movements, therefore, youth movements have also emerged in northern towns like Irbid, Jerash, Mafraq and Zarqa. Yet while each movement sees itself as independent, many also overlap in membership with the youth wings of various political parties. Indeed, in the words of journalist Taylor Luck, 'many of the popular movements are caught in a love-hate relationship of dependence with traditional opposition parties and professional associations' ${ }^{71}$ Many youth movements draw on the organisation and logistical experience of organised parties in order to generate public support for their demonstrations, even as they remain independent organisations. ${ }^{72}$

Despite setbacks such as the March 25 violence, most Jordanians remain strongly in favour of reform rather than full regime change. Meanwhile, outside Jordan, the descent into violence following the Arab uprisings in Libya, Yemen and Syria may actually have helped the Hashemite monarchy in perhaps an odd way. No Jordanian wishes to see their country take these violent paths, and such examples of social chaos may have bought the monarchy at least some more time. And most Jordanians seem willing to give the king a chance to join or lead efforts towards real democratic reform. In a nationally televised speech to the nation on 12 June 2011, the king decried disunity, fitna, and irresponsible media reporting. But he also called for strengthening the party system and for democratic governments drawn from the elected parliament, rather than appointed by royal decree. If the latter idea is indeed implemented, it meets a major demand across the reformist opposition spectrum. As one activist put it, summarising the general view, 'it's a good idea ... if it happens', because the speech omitted any timetable for implementing this key opposition demand. ${ }^{73}$

This level of instant scepticism has been well earned. Despite extensive verbal support for reform, and unveiling recurrent campaigns advocating reform, the regime had seemed to tilt more consistently in a conservative direction over the last few years, essentially siding with the more reactionary traditional elite over the reformers, at least in terms of limiting democratisation. The regime periodically provides small elements of reform and change to keep those reformers (and foreign critics) at bay, usually with new slogans and marketing campaigns having more prominence than the actual reforms. As one disappointed reform activist and former policy-maker noted, the monarchy's 'words are with the reformers, but its actions are for the status quo' ${ }^{74}$

In response to the 2011 unrest, the monarchy dismissed the government, replacing a largely technocratic business elite with more veteran political figures,

\footnotetext{
${ }^{70}$ The activists tweeted their reactions during the debate, while also receiving questions, via Twitter, from those who could not participate in person. See, for example, the Hashtag debate with former National Agenda for Reform leader, Dr. Marwan Muasher, at http://www.jordandays.tv/showVideo1.aspx?VidId = 1813 (accessed 25 July 2011).

${ }_{71}$ Luck, 'Despite Differences'.

72 Some movements have gone further organisationally, such as the Karak Popular Youth Movement, by creating a steering committee to include representatives from parties and professional associations as well as independent activists. Luck, 'Despite Differences'.

${ }_{73}$ C.R. Ryan, 'The King's Speech', Foreign Policy, Middle East Channel, 17 June 2011, http://mideast. foreignpolicy.com/posts/2011/06/17/the_kings_speech (accessed 17 July 2011).

${ }_{74}$ Author interview with reform activist, Washington, DC, June 2010.
} 
including Prime Minister Ma'aruf al-Bakhit. Bakhit, a former military officer with more than 30 years of service in the armed forces, had served earlier as prime minister, during the now discredited 2007 elections. While Bakhit may have reassured security-oriented East Jordanian nationalists and conservatives, his appointment was profoundly disappointing to democratic activists who had hoped for a reformer. In typical Hashemite politics, however, the king also appointed a more progressive veteran political leader (and one of the most influential Palestinian Jordanians in the kingdom), Senate Speaker Taher al-Masri, to head the National Dialogue Committee on reform. Both the new prime minister and the king met with leaders of the IAF and Muslim Brotherhood in an effort to cool domestic tensions and also to discuss the possibility of Islamist figures taking cabinet posts and joining the National Dialogue Committee (the Islamists refused on both counts). The regime was in full crisis mode, attempting to mollify both traditional bases of support and traditional sources of opposition. But the timehonoured techniques of reshuffling cabinets, blaming previous governments (rather than the monarchy) for failure to implement reform, and issuing royal calls for more reform will ring hollow unless followed by real reform. ${ }^{75}$

But an alternative politics is also possible, without requiring either street revolutions, overthrow of the regime or even radically disruptive change. Rather, the blueprints for greater reform have already been written, ironically under the regime's own guidance. King Abdullah has only to dust off the detailed proposals (that happen to include most opposition demands) already written by the royal National Agenda Committee, echoed later by the state-appointed National Center for Human Rights (NCHR), and endorsed by a coalition of reform-minded opposition parties. Indeed, the NCHR itself issued a statement stressing that the lack of real reform in the kingdom amounted to 'the gravest danger to the safety and security of society and to national unity'. 76

In May 2011, yet another reform coalition emerged in Jordanian politics, but one that had the potential to bridge many of the parties, groups and movements discussed in this analysis. The National Front for Reform, led by former prime minister Ahmad 'Ubaydat, included the Islamic Action Front, all the leftist parties discussed above, and the Jordanian Women's Union, and intended to bring under its umbrella the various youth movements as well. 'They [the youth movements] can be closer to the street than people our age and at the level of our political experiences,' 'Ubaydat argued, 'but they also need us and we need them. ${ }^{, 77}$

Perhaps the time has come for another convergence of regime and opposition elites-as in the 1991 National Charter-to chart the course for a more open and inclusive Jordanian system. ${ }^{78}$ Unlike the desperate flailing attempts of regimes in Libya, Syria or Yemen to stay in power, the Hashemite regime need only take its own advice. If it does so, it will once again provide an example to the region, as it did in 1989. If not, then the fire next time may consume it.

\footnotetext{
${ }^{75}$ L. Andoni, 'Jordanians Demand Change', Al-Jazeera, 21 February 2011, http://english.aljazeera.net/indepth/ opinion/2011/02/2011220105658153939.html (accessed 30 July 2011).

${ }^{76}$ NCHR: Government Negligence of Real Reform is Greatest Danger to National Unity, Security, Ammon News, 4 February 2011, http://en.ammonnews.net/article.aspx?articleNO=11507

77 A.T. Homoud, 'Reform Gets a Heavyweight', JO Magazine, 3 July 2011.

78 Al-Rantawi, 'Coalition Presses for Electoral Reform in Jordan'; National Democratic Institute, 'In Jordan, Coalition Unites for Electoral Reform', 3 March 2010, http://www.ndi.org/print/16087 (accessed 30 July 2011).
} 


\section{Conclusions}

This analysis has shown extensive levels of pro-reform and pro-democracy activism in Jordanian politics, but with little success in achieving reform. In addition to an ever-expanding number of NGOs, civil society groups, trade unions and professional associations, Jordanian politics has seen decades of opposition activism and coordination, involving established left-wing and Pan-Arab nationalist parties as well as the larger and more popular Jordanian Islamist movement (including the Muslim Brotherhood, the IAF and independent Islamists). In addition, newer reform movements have emerged, from coalitions such as the Jordanian Campaign for Change to the March 24 Shabab Movement and increasingly pervasive youth and social media activism. But for all their presence, activism and attempts at coordination, Jordan's reformers and democracy activists are more pluralist than a single reform coalition, and to date, have had limited effectiveness in achieving reform and change.

Yet in some ways, observing Jordanian reform struggles is like watching two coalitions manoeuvre and spar with one another. One is a tighter, narrower, conservative anti-reform coalition embedded in key institutions in the state itself. The other group is a set of coalitions for reform, and hence is a more broad, diverse and highly pluralistic set of groups that comprise a coalition in only the loosest possible sense. These include the traditional opposition rooted in Islamist, leftist and nationalist parties, as well as a series of youth movements, NGOs, trade unions and other pro-reform groups. This general image, however-of two sparring sets of coalitions-would seem to suggest a distinct advantage for the anti-reform coalition so deeply imbedded in the regime itself. But what is also most noticeable in the sparring between these two large sets of forces is that they sometimes appear to belong to two different centuries.

The king's own former leader of regime reform efforts, Marwan Muasher, emphasised in his report for the Carnegie Foundation that the problem is not unique to Jordan, but can indeed be found throughout the region. Entrenched elites oppose reform, he argues, because they occupy 'a privileged position that would be compromised by merit-based systems, rather than ones based on clientelism and patronage'. ${ }^{79}$ In the specific case of Jordan, he adds, the ruling elite, and especially anti-reform elites, need to realise that they are deluding themselves, but no one else. 'The political elite must recognize that the only way they can retain power is by sharing it,' Muasher argues, 'and governments will have to acknowledge that substituting serious implementation with reform rhetoric fools no one. ${ }^{80}$

Meanwhile, the layer of fear does indeed seem to have been lifted in Jordan and across the Arab world, and in some ways it is represented by the contrast between tweeting, blogging and Facebooking shabab movements, on the one hand, and the crude physical and brutal methods of the bultajiyya, on the other. The image of that contrast, in short, should serve simply to remind outside observers that most Jordanians are under the age of 30 . Most have been hearing about reform promises and campaigns all their lives. Many, but not all, are tapped into broader regional and global networks, are well educated and literate, and are not shy about voicing

\footnotetext{
${ }^{79}$ M. Muasher, A Decade of Struggling Reform Efforts in Jordan: The Resilience of the Rentier System (Washington, DC: Carnegie Endowment for International Peace, 2011), p. 4.

${ }^{80}$ Ibid., p. 23.
} 
their political views. The future, they feel, is clearly theirs and hence is a future of reform and democracy in Jordan. Yet the fact remains that the electoral delays, problematic electoral laws and other forms of de-liberalisation have only undermined public confidence in reform, political liberalisation and the regime itself.

The wildcard, as always in Jordanian politics, is the role of the king and of the palace. Some of the king's advisors are themselves dedicated reformers; most, however, seem to come from precisely the opposite camp. But these reformers remain emphatic that the king is still with them, and has simply been thwarted at seemingly every turn by an old elite that the king inherited from his late father, and a newly entrenched elite that is, ironically, largely of his own making. ${ }^{81}$ Among more grassroots reform activists, in contrast, there is considerably less faith that the monarchy is really with them. And while the instincts and goals of the democratic opposition forces remain reformist rather than revolutionary, with calls for policy change rather than regime change, the monarchy itself increasingly faces three clear choices regarding reform and democratisation that have been faced by many a government before it: lead, follow, or be forced out of the way.

\footnotetext{
${ }^{81}$ The two largest parts of the regime's ruling political elite might therefore also be seen to include more specifically an old guard largely East Jordanian elite rooted in the bureaucracy, security services and armed forces, and a newer elite (that arose with King Abdullah's accession to the throne) of more business-oriented technocratic elites, including both East Jordanians and Palestinians. In his analysis, Bustani notes that the latter group tends to be seen as 'neoliberal' but that both groups actually tend to subscribe to this ideology. See Bustani, 'The Alternative Opposition in Jordan'.
} 